\title{
L1CAM Gene
}

National Cancer Institute

\section{Source}

National Cancer Institute. L1CAM Gene. NCI Thesaurus. Code C112136.

This gene plays a role in the development of the nervous system. 